INDONESIA ACCOUNTING JOURNAL

VOLUME 1, NUMBER 2, YEAR 2019

${ }^{1}$ Corresponding author

Jurusan Akuntansi

Fakultas Ekonomi dan Bisnis

Universitas Sam Ratulangi

Jl. Kampus UNSRAT

Manado, Indonesia, 95115

E-mail: marshelakapoh@gmail.com

${ }^{2,3}$ Jurusan Akuntansi

Fakultas Ekonomi dan Bisnis

Universitas Sam Ratulangi

Jl. Kampus UNSRAT

Manado, Indonesia, 95115

Article info:

Received 16 December 2019

Accepted 16 December 2019

Available online 16 December 2019

Keywords: system implementation evaluation; cash receipt procedures JEL Classification: H11, H83

DOI: http://doi.org/10.3240o/iaj.26718

\section{Evaluasi pelaksanaan sistem dan prosedur penerimaan kas pada Badan Pengelola Pajak dan Restribusi Daerah Kabupaten Minahasa Selatan?}

\author{
Marshela Pinly Kapoh ${ }^{1}$ \\ Herman Karamoy ${ }^{2}$ \\ Harijanto Sabijono ${ }^{3}$
}

\begin{abstract}
One of which can be used as a source of local revenue is cash receipts in government agencies such as offices, other government agencies. As an autonomous region, a new paradigm has emerged in the Indonesian constitutional system which has implications for the implementarion of local government. The purpose of this study was to evaluate the implementation of the system and procedure for cash receipts at the regional tax and levies management agency in the Minahasa Regency. Based on the results of research that the implementation of system and procedures for cash receipts in the Agency for the management of tax and levies in the southern Minahasa regency is in accordance with Permendagri 59 of 2007. System and procedures for local tax and levies include registration, verification, printing, signing of tax invoice, stipulation, issuance, depositing, recording, and filling of tax documents to taxplayes or tax levies. Based on research in the field that the system and procedures for regional financial management contained in Permendagri 59 of 2007, especially in the southern Minahasa regency tax and levies management agency, have been carried out well, it is clear that overall the procedures for receiving cash from authorized officials. In accordance with the result of the study, it can be concluded several things including: the system and procedures for cash receipts blank letter of deposit (BLD) is one ot the very important documents udes in recording cash receipts at the local tax and levies management body in South Minahasa Regency.
\end{abstract}

\section{Pendahuluan}

Penerimaan kas merupakan salah satu unsur laporan keuangan yang wajib dibuat oleh setiap SKPD yang ada di lingkup pemerintah yang juga bertujuan sebagai laporan pertangggungjawaban. Di era saat ini masyarakat memiliki rasa ingin tahu yang sangat tinggi terhadap laporan keuangan pemerintah. Ini diakibatkan karena kurangnya keterbukaan pemerintah dalam mempublikasikan anggaran-anggaran belanja yang telah disusun maupun yang telah di realisasikan. Pengeluaran yang dilakukan oleh pemerintah tidak luput dari sorotan masyarakat, bahkan penerimaan atau sumber pemasukan keuangan pemerintah saat ini sudah sangat disorot oleh masyarakat.
Informasi keuangan berupa laporan keuangan diharapkan dapat memberikan gambaran secara menyeluruh mengenai perkembangan organisasi baik dari sisi potensi yang dapat dikembangkan dan juga prospek. Laporan keuangan juga menentukan keberhasilan suatu organisasi dalam mencapai tujuan dengan memanfaatkan sumber daya yang ada dan lewat sumber daya tersebut diharapkan organisasi bisa memprediksi penerimaan yang akan diterima berdasarkan pengeluaran-pengeluaran yang telah dikeluarkan. Sesuai dengan peraturan reformasi keuangan daerah saat ini, informasi keuangan bisa dikelola dan dikumpulkan melalui sistem dan prosedur yang harus diikuti oleh pemerintah untuk 
mencapai good governance dan sistem keuangan pemerintah yang baik.

\section{Tinjauan pustaka}

Sistem akuntansi penerimaan kas. Berdasarkan Permendagri No. 59 tahun 2007, sistem akuntansi penerimaan kas adalah serangkaian proses mulai pencatatan, penggolongan, dan peringkasan transaksi dan/atau kejadian keuangan serta pelaporan keuangan dalam rangka pertanggungjawaban pelaksanaan APBD yang berkenan dengan penerimaan kas pada SKPD dan/atau pada SKPKD yang dapat dilaksanakan secara manual maupun terkomputerisasi. Pelaksanaan sistem akuntansi penerimaan kas berdasarkan Permendagri No. 59 Tahun 2007adalah:

1. Tingkat SKPKD dilaksanakan oleh PPK-SKPD (Pejabat Penatausahaan Keuangan Satuan Kerja Perangkat Daerah), Bendahara Penerimaan, dan Bendahara Penerimaan Pembantu.

2. Tingkat SKPD dilaksanakan oleh PPKD (Pejabat Pengelolaan Keuangan Daerah) Fungsi Akuntansi, Bendahara Penerimaan, dan Bendahara Penerimaan Pembantu.

Dokumen yang digunakan dalam sistem akuntansi penerimaan kas berdasarkan Permendagri No. 59 tahun 2007 antara lain:

1. Surat Ketetapan Pajak Daerah (SKPD).

2. Surat Ketetapan Retribusi (SKR).

3. Surat Tanda Setoran (STS).

4. Surat Tanda Bukti Penerimaan (STBP).

5. Nota Kredit.

6. Bukti Transfer.

7. Dokumen Lainnya.

Berdasarkan Permendagri No. 59 tahun 2007, Satuan Kerja Pengelolaan Keuangan Daerah (SKPKD) adalah suatu kerja yang mempunyai tugas khusus untuk mengelola keuangan daerah. SKPKD adalah sebuah entitas akutansi yang mencatat transaksitransaksi yang dilakukan oleh SKPKD dalam kapasitas sebagai Pemda. Transaksi yang terjadi di SKPKD dapat diklasifikasikan menjadi dua, yaitu: 1) transaksi-transaksi yang dilakukan oleh SKPKD sebagai satuan kerja; dan 2) transaksi-transaksi yang dilakukan oleh
SKPKD sebagai Pemerintah Daerah, seperti pendapatan dana perimbangan, bunga, subsidi, hibah, bantuan sosial, belanja hasil, bantuan keuangan, belanja tidak terduga, transaksi-transaksi pembiayaan, pencatatan investasi, dan utang jangka panjang. Berdasarkan Permendagri No. 59 tahun 2007, fungsi akuntansi SKPKD bertugas untuk:

1. Mencatat transaksi-transaksi Pendapatan, Belanja, Pembiayaan, Aset, Utang, dan Selain Kas berdasarkan bukti-bukti yang terkait.

2. Memposting jurnal-jurnal tersebut ke dalam buku besarnya masing-masing.

3. Membuat laporan keuangan yang terdiri atas laporan realisasi Anggaran,

4. Neraca, dan Catatan atas Laporan Keuangan.

Penelitian terdahulu. Karamoy (2013) menemukan bahwa secara umum Dinas Pendapatan Kota Manado sudah menerapkan sistem dan prosedur penerimaan kas sesuai dengan ketentuan pada Permendagri No. 59 tahun 2007. Janis et al. (2015) menemukan bahwa secara umum DPPKAD Kabupaten Sitaro telah menerapkan sistem dan prosedur penerimaan PAD sesuai dengan Permendagri No. 59 tahun 2007 namun pelaksanaan pengendalian intern belum memadai pada bidang akuntansi yang belum melaksanakan pencatatan atas penerimaan PAD ke dalam buku jurnal. Tuerah (2013) menemukan bahwa pelaksanaan penerimaan yang berupa retribusi biaya penggantian KTP dan akta dan pengeluaran belanja Uang Persediaan (UP), Ganti Uang (GU), Tambahan Uang (TU), dan Langsung (LS) dengan prosedur penerbitan Surat penyediaan Dana (SPD), Pengajuan Surat Permintaan Pembayaran (SPP), Penerbitan Surat Perintah Membayar (SPM), penerbitan Surat Perintah Membayar (SPM), penerbitan Surat Perintah Pencairan Dana (SP2D), dan penerbitan Surat Pertanggungjawaban (SPJ) telah dilakukan sesuai dengan SE.900/316/BAKD dan teori efektivitas yang dipahami mencakup fungsi yang terkait, dokumen yang digunakan, catatan akuntansi dan jaringan prosedur sistem 
penerimaan dan pengeluaran kas. Paputungan (2011) menemukan bahwa sistem dan prosedur penerimaan dan pengeluaran kas yang dilakukan oleh DPPKAD Kota Manado sudah cukup memadai. Prihanto (2010) menemukan bahwa sistem dan prosedur dari penerimaan kas rawat inap RSUD Karanganyar telah sesuai sistem yang ada akan tetapi pemisahan tanggung jawab fungsional/otorisasi sangat jelas dan tanggung jawab setiap fungsi tidak penuh. Effendhi et al. (2017) menemukan bahwa sistem dan prosedur sistem penerimaan kas pada Dinas Pendapatan Kabupaten Nabire telah dilakukan sesuai dengan Permendagri No. 59 tahun 2007 yang mencakup fungsi yang terkait, aktivitas dan dokumen yang digunakan. Ratela (2015) menemukan bahwa Biro Umum Sekretariat Daerah Provinsi Sulawesi Utara telah melakukan proses penerimaan dan pengeluaran kas sesuai dengan Peraturan Menteri Dalam Negeri No. 59 tahun 2007. Erismawati dan Rosyafah (2017) menemukan bahwa pelaksanan sistem dan prosedur penerimaan kas pada Dinas Pendapatan Pengolaaan Keuangan dan Aset Kota Sidoarjo tidak sesuai dengan Permendagri No. 55 tahun 2008 yang telah di tetapkan. Hal ini dibuktikan dengan tidak terdapat Buku Rekapitulasi Penerimaan Harian dan Buku Pembantu Per Rincian Objek Penerimaan pada sistem penerimaan kas secara tunai, penerimaan kas melalui Bendahara Penerimaan, maupun penerimaan langsung pada rekening kas umum daerah. Pangalila et al. (2015) menemukan bahwa sistem dan prosedur penerimaan kas PAD pada Kabupaten Minahasa Utara sudah memadai dengan Peraturan Pemerintah No. 24 tahun 2005 tentang Standar Akuntansi Pemerintahan namun masih terkendala dengan terbatasnya sumber daya manusia dalam menjalankan sebagian bidang dari DPPKAD Kabupaten Minahasa Utara. Pemerintah Minahasa Utara sebaiknya merekrut orang-orang yang mampu mengatasi permasalahan sumber daya manusia yang masih kurang di DPPKAD tersebut. Karundeng et al. (2015) menemukan bahwa secara umum DPPKAD

Kabupaten Kepulauan Sitaro telah menerapkan sistem dan prosedur penerimaan pendapatan daerah melalui bendahara penerimaan sesuai dengan Permendagri No. 59 tahun 2007 namun pelaksanaan pengendalian intern belum memadai pada bidang akuntansi yang belum melaksanakan pencatatan atas penerimaan PAD ke dalam buku jurnal. Mawikere dan Tinangon (2016) menemukan bahwa sistem dan prosedur penerimaan retribusi kebersihan daerah telah sesuai dengan Permendagri No. 59 tahun 2007. Tamboto et al. (2015) menemukan bahwa pelaksanaan penerimaan kas khususnya penerimaan pajak di Dinas Pendapatan, Pengelolaan Keuangan dan Barang Milik Daerah (DPPKBMD) Kota Tomohon sudah sesuai dengan Permendagri No. 59 tahun 2007 Pasal 89 yang mencakup fungsi, dokumendokumen, dan catatan-catatan yang digunakan. serta sistem pelaksanaannya telah dilaksanakan dengan baik dan dinyatakan telah sesuai dengan peraturan yang berlaku. Christy dan Kurniawati (2016) menemukan bahwa prosedur operasional standar pengelolaan keuangan daerah yang diterapkan di Provinsi Papua mengacu pada salah satunya yaitu Permendagri No. 59 tahun 2007. Polii et al. (2018) menemukan bahwa pelaksanaan penerimaan pajak dan retribusi daerah pada Badan Pengelola Pajak dan Retribusi Daerah Kota Manado (BP2RD) Kota Manado telah sesuai dengan Permendagri No. 59 tahun 2007 meliputi fungsi yang terkait dan dokumen yang digunakan.

\section{Metode penelitian}

Jenis data. Jenis data yang digunakan dalam penelitian ini meliputi data kualitatif berupa bahan keterangan dalam bentuk uraian kata-kata dan tidak diukur dalam skala numerik berupa data tentang peraturan pemerintah mengenai standar akuntansi pemerintahan, peraturan daerah dan peraturan presiden tentang pengadaan barang/jasa pemerintah, dan data kuantitatif berupa Laporan Pelaksanaan Sistem dan Prosedur Penerimaan Kas pada Badan 
Pengelola Pajak dan Retribusi Daerah Kabupaten Minahasa Selatan.

Metode pengumpulan data. Pengumpulan data dilakukan dengan beberapa metode yakni : (1) teknik wawancara; dan (2) metode dokumentasi.

Metode analisis data. Metode analisis data yang digunakan adalah metode analisis deskriptif yaitu suatu metode yang membandingkan antara konsep-konsep teori dan peraturan-peraturan dalam mengevaluasi pelaksanaan sistem dan prosedur penerimaan kas pada Badan Pengelola Pajak dan Retribusi Daerah Kabupaten Minahasa Selatan.

\section{Hasil penelitian dan pembahasan \\ Hasil penelitian}

Semua penerimaan daerah di Kabupaten Minahasa Selatan yang dalam rangka pelaksanaan urusan pemerintahan daerah dikelola dalam APBD. Dinas Pendapatan mempunyai tugas melaksanakan kewenangan Otonomi Daerah Kota dalam rangka pelaksanaan tugas desentralisasi, dimana dalam tugas penerimaan kas yaitu memungut dan/atau menerima pendapatan daerah wajib melaksanakan pemungutan dan/atau penerimaan berdasarkan ketentuan yang ditetapkan dalam peraturan perundangundangan. Jaringan prosedur yang membentuk sistem penerimaan kas sebagai berikut:

1. Fungsi pihak terkait adalah PPK-SKPD, Pengguna Anggaran, Bendahara Penerimaan dan BUD (Bank).

2. Dokumen yang digunakan adalah Surat Tanda Setor (STS), Surat Setoran Pajak (SSP), Surat Setoran Retribusi (SSR), Surat Ketetapan Retribusi Daerah (SKRD), Surat Tanda Bukti Penerimaan (STBP), Bukti Transfer, dan Nota Kredit Bank.

3. Catatan yang digunakan adalah Buku Jurnal Penerimaan Kas, Buku Besar dan Buku Besar Pembantu.

4. Prosedur-prosedur yang dilakukan adalah: Pengguna Anggaran menyerahkan Surat Ketetapan Retribusi (SKR) yang telah diterbitkan kepada
Bendahara Penerimaan untuk melakukan verifikasi saat penerimaan pendapatan. Wajib Pajak/Wajib Retribusi menyerahkan uang. Bendahara Penerimaan kemudian melakukan verifikasi penerimaan uang dengan SKP/SKR yang bersangkutan. Setelah melakukan verifikasi, Bendahara Penerimaan mengeluarkan STBP dan Bendahara menyiapkan STS. Bendahara Penerimaan kemudian melakukan penyetoran kepada bank disertai STS. STS yang telah diotorisasi diterima kembali oleh Bendahara Penerimaan sebagai bukti pembukuan.

Prosedur penerimaan pajak daerah meliputi:

1. Pendaftaran Wajib Daerah Pajak. Tata cara pendaftaran wajib pajak sesuai dengan Peraturan Daerah Kabupaten Minahasa Selatan No. 1 tahun 2011 pasal 61 yaitu: (a) setiap wajib pajak diwajibkan mengisi formulir pendataan; (b) formulir pendataan sebagai dimaksud pada ayat (a) dengan jelas, benar dan lengkap serta ditandatangani oleh wajib pajak atau kuasanya; (c) formulir pendataan yang dimaksud dalam ayat (a) harus disampaikan kepada Bupati atau pejabat yang ditunjuk selambat-lambatnya 15 (lima belas) hari setelah berakhirnya masa pajak; dan (d) bentuk, isi dan tata cara pengisian formulir pendataan ditetapkan melalui Peraturan Bupati.

2. Verifikasi. Pencetakan dan Penandatanganan Surat Pemberitahuan Tagihan Pajak (SPTP).

3. Penetapan. Tata cara penetapan pajak yaitu: (a) pemungutan pajak dilarang diborongkan; (b) setiap wajib pajak membayar yang terutang berdasarkan penetapan Bupati atau dibayar sendiri oleh wajib pajak berdasarkan peraturan perundang-undangan perpajakan; dan (c) jenis pajak yang dipungut berdasarkan penetapan atau dibayar sendiri oleh wajib pajak.

4. Penerbitan. Prosedur penerbitan pajak meliputi: (a) tata cara penerbitan SKPD atau dokumen lain yang dipersamakan SPTPD/SSPD, SKPDKB, dan 
SKPDKBT; (b) ketentuan lebih lanjut mengenai tata cara pengisian dan penyampaian SKPD atau dokumen lain yang dipersamakan; (c) Bupati menerbitkan STPD jika pajak dalam tahun berjalan tidak atau kurang dibayar, SPTPD terdapat kekurangan pembayaran akibat salah tulis dan/atau salah hitung, atau wajib pajak dikenakan sanksi administratif berupa bunga dan/atau denda; (d) jumlah kekurangan pahak yang terutang dalam STPD ditambah dengan sanksi administratif berupa bunga sebesar $2 \%$ (dua persen) setiap bulan untuk paling lama 15 (lima belas) bulan sejak saat terhutangnya pajak; dan (e) SKPD yang tidak atau kurang dibayar setelah jatuh tempo pembayaran dikenakan sanksi administratif berupa bunga sebesar $2 \%$ (dua persen) sebulan dan ditagih melalui STPD.

5. Penyetoran. Tata cara pembayaran atau penyetoran pajak dilakukan sebagai berikut: (a) pembayaran pajak melalui kas daerah atau bendahara penerimaan dinas atau tempat lain yang ditunjuk oleh Bupati atau pejabat; (b) apabila pembayaran pajak dilakukan di tempat lain yang ditunjuk, hasil penerimaan harus disetor ke kas daerah selambatlambatnya 1 x 24 jam atau dalam waktu yang ditentukan oleh Bupati; dan (c) pembayaran atau penyetoran pajak sebagaimana dimaksud pada bagian (a) dan bagian (b) dilakukan dengan menggunakan Surat Setoran Pajak Daerah (SSPD) yang merupakan bukti pembayaran atau penyetoran pajak yang telah dilakukan dengan menggunakan formulir atau dilakukan dengan cara lain ke kas daerah melalui tempat pembayaran yang ditunjuk oleh Kepala Daerah dan/atau dokumen lain yang dipersamakan.

6. Pencatatan, dan pengarsipan dokumen pajak.

7. Penyerahan dokumen pajak ke wajib pajak. Penyerahan dokumen pajak berupa blanko Surat Ketetapan Pajak Daerah (SKPD), Surat Setoran Pajak Daerah (SSPD) dan Surat Tanda Setoran (STS).
Prosedur Penerimaan Retribusi Daerah yaitu:

1. Pendaftaran Wajib Retribusi Daerah.

2. Verifikasi, Pencetakan, dan Penandatanganan.

3. Penerimaan dan Penyetoran Retribusi daerah melalui Bendahara.

4. Penyetoran retribusi daerah dari Wajib Retribusi ke Bendahara Penerimaan Surat Ketetapan Pajak Daerah (SKPD).

5. Penyetoran Retribusi daerah dari Wajib Retribusi ke bendahara Penerimaan Surat Ketetapan Pajak Daerah (SKPD).

6. Pencatatan dan Pengarsipan Dokumen untuk Wajib Retribusi.

\section{Pembahasan}

Evaluasi Pelaksanaan Sistem dan Prosedur Penerimaan Kas berdasarkan Permendagri No. 59 tahun 2007, bahwa pelaksanaan penerimaan kas dilakukan melalui prosedur penerimaan STS yang dikeluarkan oleh Bank dan selanjutnya dikirimkan ke fungsi yang melaksanakan nya. Karena itu peraturan daerah yang berkaitan dengan sistem dan prosedur harus dirancang sedemikian rupa dan secara hatihati supaya antara ketentuan satu dengan yang lainnya dapat saling berkesesuaian secara efisien dan efektif. Penelitian ini menganalisis kesesuaian sistem penerimaan kas pada Badan Pengelola Pajak dan Retribusi Daerah Kabupaten Minahasa Selatan khususnya Bendahara Penerimaan dengan sistem dan prosedur yang tertuang dalam Permendagri No. 59 Tahun 2007. Evaluasi dilakukan atas sistem akuntansi penerimaan kas. Berdasarkan penelitian di lapangan bahwa sistem dan prosedur pengelolaan keuangan Daerah yang tertuang dalam pemendagri 59 tahun 2007 khususnya di Badan Pengelola Pajak dan Retribusi Daerah Kabuapten Minahasa Selatan telah di lakukan dengan baik, terlihat jelas secara keseluruhan prosedur penerimaan kas oleh pejabat yang berwenang. Sedangkan dokumen-dokumen yang digunakan juga sudah sesuai dengan bentuk-bentuk dokumen. Sistem dan prosedur penerimaan daerah melalui 
Bendahara Penerimaan adalah sebagai berikut:

1. Pengguna anggaran menyerahkan SKP Daerah kepada wajib pajak dan bendahara penerimaan.

2. Wajib pajak membayarkan uang kepada Bendahara Penerimaan sejumlah yang tertera di SKP Daerah.

3. Bendahara Penerimaan melakukan verifikasi uang yang diterimanya dengan SKP Daerah dari pengguna anggaran.

4. Jika sesuai maka Bendahara Penerimaan membuat dokumen STS dan Surat tanda bukti pembayaran/bukti lain yang sah.

5. Bendahara Penerimaan menyerahkan surat tanda bukti bukti pembayaran/bukti lain yang sah kepada wajib pajak dan STS beserta uang kepada bank.

6. Bank mengotorisasi STS dan menerbitkan nota kredit, Bank mengembalikan STS bendahara Penerima, dan Nota kredit disampaikan ke BUD.

Berdasarkan PP No. 60 tahun 2008 dalam unsur-unsur penting dalam sistem pengendalian intern Pemerintah. Evaluasi dalam unsusr-unsur sebagai berikut:

1. Lingkungan pengendalian. Terjalinnya komunikasi dengan baik, adanya komitmen pegawai terhadap kompetensi masing-masing, terciptanya partisipasi yang aktif oleh semua pihak yang bertanggung jawab atau tata kelola, terbentuknya struktur organisasi pemerintahan secara rinci, adanya pemberian wewenang dan tanggung jawab khususnya di Badan Pengelola Pajak dan Retribusi Daerah Kabupaten Minahasa Selatan, serta tersusunnya kebijakan yang mendukung praktik kerja pegawai.

2. Proses penilaian risiko. Badan Pengelola Pajak dan Retribusi Daerah Kabupaten Minahasa Selatan sudah melibatkan manajemen terhadap prosedur penerimaan kas dalam hal: (a) mengidentifikasi dan menganalisis risiko yang relevan dengan laporan keuangan; (b) mengestimasi sifnifikansi risiko tersebut; (c) menilai kemungkinan keterjadian risiko tersebut; dan (d) merespon dan menentukan bagaimana seharusnya mengelola risiko tersebut.

3. Kegiatan pengendalian. Badan Pengelola Pajak dan Retribusi Daerah Kabupaten Minahasa Selatan telah melakukan partisipasi aktif manajemen dalam melaksanakan kebijakan dan prosedur untuk menghadapi risiko dari penerimaan kas yang berkaitan dengan hal-hal sebagai berikut: (a) reviu satas kinerja instansi pemerintah yang bersangkutan; (b) pengendalian atas pengelolaan sistem informasi; (c) penelahaan kinerja; (d) pengolahan informasi; (e) pengendalian fisik; dan (f) pemisahan fungsi.

4. Informasi dan komunikasi. Sistem informasi dan komunikasi di Badan Pengelola Pajak dan Retribusi Daerah Kabupaten Minahasa Selatan sudah relevan dengan pelaporan keuangan yaitu dengan adanya keterlibatan manajemen dalam menyusun serta menerapkan sistem informasi yang mencakup metode dan waktu yang tepat.

5. Pemantauan. Pada Badan Pengelola Pajak dan Retribusi Daerah Kabupaten Minahasa Selatan telah dilakukan berbagai keterlibatan manajemen dalam memantau langsung pelaksanaan sistem intern prosedur penerimaan kas secara berkala melalui: pemantauan berkelanjutan, evaluasi terpisah, dan tindak lanjut rekomendasi hasil audit dan reviu lainnya.

\section{Kesimpulan dan saran}

Penelitian ini melakukan evaluasi sistem dan prosedur penerimaan kas pada Badan Pengelola Pajak dan Retribusi Daerah Kabupaten Minahasa Selatan karena penerimaan kas merupakan sumber daya yang sangat penting di dalam melaksanakan program pembangunan yang telah direncanakan oleh pemerintah khususnya pada Badan Pengelola Pajak dan Retribusi Daerah Kabupaten Minahasa Selatan, sesuai dengan hasil penelitian tersebut dapat disimpulkan beberapa hal sebagai berikut: 
1. Pelaksanaan penerimaan pajak dan retribusi daerah pada Badan Pengelola Pajak dan Retribusi Daerah Kabupaten Minahasa Selatan sudah dilakukan sesuai dengan Permendagri 59 tahun 2007 yang meliputi fungsi yang terkait, dan dokumen yang digunakan.

2. Pelaksanaan sistem dan prosedur penerimaan kas dilakukan oleh beberapa fungsi yaitu, pada dinas selaku fungsi yang menyetor penerimaan kas, Bank selaku lembaga keuangan yang dipakai oleh Badan Pengelola Pajak dan Retribusi Daerah serta Bendahara Penerimaan sebagai fungsi yang mengesahkan.

3. Pelaksanaan penerimaan pajak dan retribusi daerah pada Badan Pengelola Pajak dan Retribusi Daerah Kabupaten Minahasa Selatan sudah dilakukan sesuai dengan PP No. 60 tahun 2008 tentang Sistem Pengendalian Intern Pemerintah yaitu dari segi lingkungan pengendalian, penilaian risiko, sistem informasi, dan komunikasi, kegiatan pengendalian, dan pemantauan.

4. Sistem dan prosedur penerimaan kas Blanko Surat Tanda Setor (STS) adalah salah satu dokumen yang sangat penting digunakan pada pencatat penerimaan kas pada Badan Pengelola Pajak dan Retribusi Daerah di Kabupaten Minahasa Selatan.

\section{Daftar pustaka}

Christy, Y., \& Kurniawati, E. (2016). Evaluasi penerapan prosedur operasional standar pengelolaan keuangan daerah di Provinsi Papua. Jurnal Ekonomi dan Bisnis, 17(1), 49-72. https://doi.org/https://doi.org/10.24914/jeb.v $17 i 1.239$

Effendhi, R., Sondakh, J., \& Budiarso, N. (2017). Evaluasi sistem dan prosedur penerimaan Pendapatan Asli Daerah (PAD) Kabupaten Nabire. Going Concern : Jurnal Riset Akuntansi, 12(2), 9901000. https://doi.org/10.32400/gc.12.2.18502.2017

Erismawati, D. Y., \& Rosyafah, S. S. (2017). Analisa pelaksanaan sistem dan prosedur penerimaan arus kas pada Dinas Pendapatan Pengelolaan Keuangan dan Aset Kota Sidoarjo. Equity, 3(2), 174-189. http://fe.ubhara.ac.id/ojs/index.php/equity/arti cle/view/422
Janis, R. S., Sondakh, J., Sabijono, H. (2015). Analisis sistem dan prosedur penerimaan pada pada Dinas Pendapatan Pengelolaan Keuangan dan Aset Daerah Kabupaten Sitaro, Jurnal EMBA: Jurnal Riset Ekonomi, Manajemen, Bisnis dan Akuntansi, $\quad 3(1), \quad$ 778-786. https://ejournal.unsrat.ac.id/index.php/emba/a rticle/view/7552

Karamoy, R. L. (2013). Evaluasi pelaksanaan sistem dan prosedur penerimaan kas pada Dinas Pendapatan Kota Manado. Jurnal EMBA: Jurnal Riset Ekonomi, Manajemen, Bisnis dan Akuntansi, 1(3), 939-948. https://ejournal.unsrat.ac.id/index.php/emba/a rticle/view/1903

Karundeng, C. N, Ilat, V., \& Runtu, T. (2015). Analisis prosedur penerimaan pendapatan daerah melalui bendahara penerimaan pada Dinas Pendapatan Pengelolaan Keuangan dan Aset Daerah (DPPKAD) Kabupaten Kepulauan Sitaro. Jurnal Berkala Ilmiah Efisiensi, 15(4), 28-39. https://ejournal.unsrat.ac.id/index.php/jbie/arti cle/view/9374

Mawikere, L. M., \& Tinangon, J. J. (2016). Analisis sistem dan prosedur penerimaan retribusi kebersihan daerah pada Dinas Pendapatan Daerah Kota Manado. Jurnal Berkala Ilmiah Efisiensi, 16(4), 612-622.

https://ejournal.unsrat.ac.id/index.php/jbie/arti cle/view/13699

Pangalila, C. M., Kalangi, L., \& Budiarso, N. (2015). Analisis sistem dan prosedur penerimaan kas Pendapatan Asli Daerah (PAD) pada DPPKAD Kabupaten Minahasa Utara. Jurnal Berkala Ilmiah Efisiensi, 15(4), 366-377. https://ejournal.unsrat.ac.id/index.php/jbie/arti cle/view/9638

Paputungan, R. (2011). Analisis pelaksanaan sistem dan prosedur penerimaan pengeluaran kas pada Dinas Pendapatan Pengelolaan Keuangan dan Aset Daerah Kotamobagu. Skripsi: Fakultas Ekonomi, Universitas Sam Ratulangi, Manado.

Polii, J., Elim, I., \& Pusung, R. (2018). Analisis sistem dan prosedur penerimaan kas Pendapatan Asli Daerah (PAD) pada Badan Pengelola Pajak dan Retribusi Daerah Kota Manado. Going Concern : Jurnal Riset Akuntansi, 13(04). https://doi.org/10.32400/gc.13.04.21808.2018

Prihanto. (2010). Evaluasi sistem informasi akuntansi penerimaan kas dari instalasi rawat inap pada RSUD. Karanganyar. Tugas Akhir: Fakultas Ekonomi, Universitas Sebelas Maret. https://digilib.uns.ac.id/dokumen/detail/16530 /Evaluasi-sistem-informasi-akuntansipenerimaan-kas-dari-instalasi-rawat-inap-padaRSUD-Karanganyar

Ratela, S. R. (2015). Analisis akuntansi atas penerimaan dan pengeluaran kas pada Biro Umum Sekretariat Daerah Provinsi Sulawesi Utara. Jurnal EMBA: Jurnal Riset Ekonomi, Manajemen, Bisnis dan Akuntansi, $\quad 3(4), \quad 269-276$. https://ejournal.unsrat.ac.id/index.php/emba/a rticle/view/10791

Republik Indonesia. (2007). Peraturan Menteri Dalam Negeri No. 59 tentang Pedoman Pengelolaan Keuangan Daerah.

Tamboto, J. A., Tinangon, J., \& Elim, I. (2015). Evaluasi pelaksanaan sistem dan prosedur penerimaan kas 
pada Dinas Pendapatan, Pengelolaan Keuangan dan Barang Milik Daerah Kota Tomohon. Jurnal

EMBA: Jurnal Riset Ekonomi, Manajemen, Bisnis dan Akuntansi, 3(4), 671-679.

https://ejournal.unsrat.ac.id/index.php/emba/a rticle/view/11157

Tuerah, F. S. (2013). Evaluasi pelaksanaan sistem dan prosedur penerimaan dan pengeluaran kas Dinas Kependudukan dan Pencatatan Sipil Minahasa Tenggara. Jurnal EMBA: Jurnal Riset Ekonomi, Manajemen, Bisnis dan Akuntansi, 1(3), 443-453. https://ejournal.unsrat.ac.id/index.php/emba/a rticle/view/2059 